\title{
PENDIDIKAN BERBASIS AGAMA, FILSAFAT, PSIKOLOGI DAN SOSIOLOGI
}

\author{
Gunawan $^{1}$, Ujang Nurjaman ${ }^{2}$ \\ ${ }^{1}$ Sekolah Pascasarjana Universitas Islam Nusantara, Bandung, Indonesia \\ Gunawan@gmail.com \\ ${ }^{2}$ Sekolah Pascasarjana Universitas Islam Nusantara, Bandung, Indonesia \\ Ujangnurjaman@gmail.com
}

\begin{abstract}
Abstrak
Dewasa ini pendidikan kita yang diharan mampu mengangkat ketidakberdayaan masyarakat agar tumbuh dan berkembang serta dapat mensejahterakan ternyata masih memiliki banyak masalah yang terus menyelimutinya. Banyak perilaku masyarakat yang tidak lagi menghormati norma-norma susila dan agama, tawuran antar pelajar dan penyimpangan-penyimpangan lainnya. Hal ini semakin mempertegas bahwa pendidikan kita perlu mengembangkan dan mengedepankan nilai-nilai yang dapat menjadi pedoman masyarakat. Tujuan penelitian ini dirancang untuk mendefinisikan pendidikan berbasis agama, filasafat, psikologi dan sosilogi. Metode penelitian yang digunakan peneliti adalah metode library research. Pengumpulan data yang dilakukan peneliti adalah dengan mengumpulkan ragam literatur dan dianaliss dengan tekhnik analisis data serta content analysis sebagai pisau analisis. Lembaga pendidikan seperti halnya sekolah dan pesantren memegang peranan penting dalam mengembangkan nilai-nilai tersebut, sehingga dapat menjadi pedoman bagi para peserta didik atau santri untuk menjalani kehidupannya. Sistem nilai dalam proses pendidikan kehidupan manusia tidak lepas dari nilai, dan nilai itu selanjutnya perlu diinstitusikan yang tentunya institusionalisasi nilai yang terbaik adalah melalui upanya pendidikan.
\end{abstract}

Kata Kunci: Pendidikan, Agama, Filsafat, Psikologis, Sosiologis

\section{PENDAHULUAN}

Hampir setiap orang pernah mengalami pendidikan, tetapi tidak setiap orang mengerti makna kata pendidikan, pendidik, dan mendidik. Untuk memahami pendidikan, ada dua istilah yang dapat mengarahkan pada pemahaman hakikat pendidikan, yakni kata paedagogie dan paedagogiek. Paedagogie bermakna pendidikan sedangkan paedagogiek berarti ilmu pendidikan. Oleh karena itu, tidaklah mengherankan apabila paedagogik atau ilmu mendidik adalah ilmu atau teori yang sistematis tentang pendidikan yang sebenarnya bagi anak atau untuk anak sampai ia mencapai kedewasaan. ${ }^{1}$

Hal ini seperti yang diungkapkan menurut Triwiyanto: ${ }^{2}$

${ }^{1}$ M Sukardjo dan Ukim Komarudin, Landasan Pendidikan Konsep dan Aplikasi (Jakarta: PT Raja Grafindo Persada, 2010), h. 7.

${ }^{2}$ Teguh Triwiyanto, Pengantar Pendidikan (Jakarta: PT Bumi Aksara, 2014), h. 19.

Al Qalam: Jurnal Ilmiah Keagamaan dan Kemasyarakatan Vol. 16, No. 1

Januari - Juni 2022 
Gunawan, Ujang Nurjaman : Pendidikan Berbabis Agama, Filsafat, Psikologi dan Sosiologi

bahwa dalam mengkaji hakikat pendidikan akan memberikan landasan yang kuat terhadap praktik pendidikan dalam upaya memanusiakan manusia. Hakikat pendidikan menjadikan arah pendidikan menjadi kokoh dan kuat untuk memuliakan manusia. Upaya dalam praktik pendidikan perlu mendasarkan diri pada hakikat pendidikan sebagai tiang penyangganya. Hakikat pendidikan adalah suatu proses menumbuh kembangkan eksistensi peserta didik yang memasyarakat, membudaya, dalam tata kehidupan yang berdimensi local.

Pendidikan di Indonesia pada kenyataannya tidak lepas dengan berbagai macam permasalaha. Permasalan pendidikan adalah segala sesuatu hal yang merupakan masalah pelaksanaan kegiatan pendidikan. Berbicara mengenai pendidikan merupakan aspek dasar kehidupan manusia, seseorang bukan hanya mendapatkan ilmu pengetahuan, tetapi juga diajarkan untuk berakhlak baik dan berbudi pekerti luhur. Berbekal pendidikan, seseorang akan menjadi orang yang berguna, bermanfaat, berilmu, sehingga mampu meningkatkan taraf hidup atau memperbaiki nasib ke arah yang lebih baik.

Salah satu faktor rendahnya kualitas pendidikan di Indonesia adalah karena lemahnya para guru dalam menggali potensi anak. Para pendidik seringkali memaksakan kehendaknya tanpa pernah memperhatikan kebutuhan, minat dan bakat yang dimiliki siswanya.

Nampak jelas bahwa masalah yang serius dalam peningkatan mutu pendidikan di Indonesia adalah rendahnya mutu pendidikan di berbagai jenjang pendidikan, baik pendidikan formal maupun informal. Dan hal itulah yang menyebabkan rendahnya mutu pendidikan yang menghambat penyediaan sumber daya manusia yang mempunyai keahlian dan keterampilan untuk memnuhi pembangunan bangsa di berbagai bidang.

Namun berbeda, ketika melihat ke sisi yang lain, sungguh begitu bertolak belakang, yaitu jika melihat lebih mendalam akan kondidi keseluruhan pendidikan yang ada di berbagai tempat di Indonesia ini, banyak ketidakmerataan dan jauh dari kesan maju (dalam hal pendidikan). Hal tersebut, terlihat dari sekolah yang jauh dari kelayakan, kondisi sekolah, dan sebagainya. Padahal, di dalamnya terdapat banyak pelajar yang begitu bersemangat untuk belajar dan menuntut ilmu, namun karena keterbelakangan akses dan juga berbagai kekurangan lainnya, yang membuat mereka sulit dalam mencapai tujuan dan cita-citanya. Meski menjadi prioritas utama Indonesia, pada praktiknya, pendidikan saat ini banyak menemui masalah. Masalah ini disebabkan beragam faktor. Berikut faktor yang seringkali menjadi masalah utama pelaksanaan pendidikan, antara lain:

1. Kekurangan Jumlah Guru Yang Terampil. Guru adalah salah satu elemen pendidikan agar proses belajar mengajar berjalan dengan lancar. Prosesnya guru mentransfer ilmu kepada murid, baik itu ilmu pengetahuan, keterampilan, serta mengajarkan pendidikan akhlak kepada murid. Faktanya yang terjadi di lapangan, pendidikan seringkali mendapat masalah

Al Qalam: Jurnal Ilmiah Keagamaan dan Kemasyarakatan Vol. 16, No. 1 Januari - Juni 2022 
kekurangan jumlah guru. Terutama guru-guru terampil atau yang bersertifikasi. Hal itu nyata terjadi di Indonesia. Penyebaran jumlah guru disekolah kadangkala tidak merata, sehingga ada yang kelebihan dan kekurangan tenaga pendidik. Bukan hanya masalah jumlah guru, persoalan lain yang muncul adalah gaji guru yang rendah, kurangnya perhatian pemerintah pada status guru, seperti guru honorer, dan masih banyak masalah lainnya.

2. Infrastruktur Pendidikan Yang Kurang atau Tidak Memadai. Dibeberapa stasiun televisi yang membawa berita bangunan sekolah yang ambruk di berbagai daerah yang ada di Indonesia akibat cuaca buruk atau ambruk memang kondisi bangunan sudah using dan rusak parah, tapi tidak juga diperbaiki. Itulah masalah lain di dunia pendidikan, termasuk Indonesia.

Padahal ruang kelas, bangunan sekolah, dan perlengkapannya menjadi vital dalam proses belajar mengajar disekolah. Namun sering terjadi kapasitasnya tidak cukup atau sudah ketinggalan zaman. Belum lagi akses pendidikan anak yang jauh dari kata bagus, seperti internet, perlengkapan seperti (komputer, smartpone), jaringan yang mendukung serta berbagai akses lainnya yang dapat mendukung proses belajar anak.

3. Kurangnya Bahan Pembelajaran Bagi Siswa atau Guru. Hambatan dunia pendidikan lain adalah kurangnya bahan pembelajaran bagi siswa dan guru, seperti buku atau bahan bacaan lain. Ini juga masalah yang cukup serius. Bagaimana siswa dan guru mampu belajar atau menambah ilmu, jika bahannya saja tidak ada. Terutama sekolah yang ada di pelosok yang sulit untuk menerima buku karena hambatan akses perjalanan yang cukup sulit untuk ditempuh. Hal ini harus menjadi perhatian pemerintah. Menyediakan bahan pembelajaran sebanyak mungkin dan mencari solusi untuk akses sekolah yang sulit ditempuh. Bisa dalam bentuk cetak perpustakaan, maupun elektronik atau online. Bahan pembelajaran tersebut sebaiknya dapat dikases secara gratis.

Pendidikan yang kini menjadi harapan mengarahkan pada kehidupan yang lebih baik hendaknya selalu berangkat dari tujuan yang akan dicapai. Apabila tujuan yang akan dicapai sudah jelas, maka langkah selanjutnya dapat diteruskan dengan memikirkan perangkat-perangkat lain yang mendukung pencapaian tujuan secara efektif dan efisien. Dari uraian di atas, maka penulis tertarik mengangkat tema makalah dengan judul: Pendidikan Berbasis Agama, Filsafat, Psikologi, Dan Sosiologi. Pentingnya pendidikan dapat diartikan sebagai sebuah kondisi dimana pendidikan menjadi sesuatu hal yang sangat penting untuk dilaksanakan sehingga dapat memaksimalkan semua unsur yang ada dalam pendidikan untuk mengembangkan potensi diri sehingga memiliki kekuatan spiritual keagamaan, pengendalian diri, kepribadian, kecerdasan, akhlak mulia, serta keterampilan yang diperlukan oleh dirinya, masyarakat, bangsa dan negara" .

Al Qalam: Jurnal Ilmiah Keagamaan dan Kemasyarakatan Vol. 16, No. 1 Januari - Juni 2022 
Dari uraian di atas dapat dirumuskan permasalahan dalam makalah ini, yaitu: Bagaimana implementasi pendidikan berbasis agama, filsafat, psikologi, dan sosiologi. Tujuan dari penulisan makalah ini adalah untuk mengetahuii, menganalisis dan mendapatkan gambaran pendidikan berbasis agama, filsafat, psikologi, dan sosiologi.

\section{METODE PENELITIAN}

Penelitian ini merupakan penelitian library research yang dalam pengumpulan datanya peneliti mengumpulkan ragam literatur dari berbagai disiplin ilmu sehingga bisa memberikan pandangan luas terkait pendidikan. Data yang sudah dikumpulkan kemudian dianalisis menggunakan content analysis sebagai pisau analisisnya sehingga ditemukan ragam pandangan yang bisa saling melengkapi antar disiplin ilmu yang ingin digali oleh peneliti.

\section{HASIL DAN PEMBAHASAN}

Secara historis pendidikan sudah ada sejak manusia ada dimuka bumi ini. Ketika kehidupan masih sederhana, orang tua mendidik anaknya, atau anak belajar kepada orang tuanya atau orang lain yang lebih dewasa di lingkungannya, seperti cara makan yang baik, cara membersihkan badan, bahkan tidak jarang anak belajar dari lingkungannya atau alam sekitarnya. Anak-anak belajar bercocok tanam, berburu dan berbagai kehidupan keseharian. Intinya anak belajar agar mampu menghadapi tugas-tugas kehidupan, mecari solusi untuk memecahkan dan mengatasi problem yang dihadapi sehari-hari. ${ }^{3}$

Sejak manusia menghendaki kemajuan dalam kehidupan, maka sejak itu timbul gagasan untuk melakukan pengalihan, pelestarian dan pengembangan kebudayaan melalui pendidikan. Maka dalam sejarah pertumbuhan masyarakat, pendidikan senantiasa menjadi perhatian utama dalam rangka memajukan kehidupan generasi demi generasi sejalan dengan tuntutan kemajuan masyrakat. Menurut keyakinan kita, sejarah pembentukan masyarakt dimulai sejak keluarga Adam dan Hawa sebagai unit kecil dari masyarakat besar umat manusia dimuka bumi ini. Dalam keluarga Adam itulah telah dimulai proses kependidikan umat manusia, meskipun dalam ruang lingkup terbatas sesuai dengan kebutuhan untuk mempertahankan kehidupannya. ${ }^{4}$

Pendidikan berkembang dari yang sederhana (primitive) yang berlangsung dari zaman dimana manusia masih berada dalam ruang lingkup kehidupan yang serba sederhana. Tujuan-tujuan pun amat terbatas pada hal-hal yang bersifat survival (pertahan hidup dari ancaman alam sekitar). Yaitu keterampilan membuat alat-alat untuk mencari dan memproduksi bahan-bahan kebutuhan

\footnotetext{
${ }^{3}$ Ros Arianti Abas, "Konsep Kecerdasan Majemuk Perspektif howard Gardner Dan Penerapanya Dalam Pembelajaran Pendidikan Agama Islam Di Sekolah,” 2016, h. 14.

${ }^{4}$ Syarifatul Marwiyah, "Konsep Pendidikan Berbasis Kecakapan Hidup,” Jurnal Falasifa 3, no. 1 (2012): h. 76.
}

Al Qalam: Jurnal Ilmiah Keagamaan dan Kemasyarakatan Vol. 16, No. 1 Januari - Juni 2022 
hidup, beserta pemeliharaanya, serta disesuaikan dengan kebutuhannya. Akan tetapi ketika manusia telah dapat membentuk masyarakat yang semakin berbudaya dengan tuntutan hidup yang semakin tinggi, maka pendidikan ditujukan bukan hanya pada pembinaan keterampilan, melainkan kepada pengembangan kemapuan-kemampuan teoritis dan praktis berdasarkan konsep-konsep berfikir ilmiah, atau lebih jelasnya masalah kehidupan dan fenomena alam kemudian diupayakan dapat dijelaskan secara keilmuan.

Persoalan pendidikan pada hakekatnya merupakan persoalan yang berhubungan langsung dengan kehidupan manusia dan mengalami perubahan serta perkembangan sesuai dengan kehidupan tersebut baik secara teori maupun secara konsep oprasionalnya. ${ }^{5}$

Pendidikan merupakan salah satu unsur dari aspek sosial budaya yang berperan sangat strategis dalam pembinaan suatu keluarga, masyarakat, atau bangsa. Kestrategisan peranan ini pada intinya merupakan suatu ikhtiar yang dilaksanakan secara sadar, sistematis, terarah dan terpadu untuk memanusiakan peserta didik serta menjadikan mereka sebagai khalifah dimuka bumi dengan berbekal kecakapan hidup.

Menurut Sholichah, A. S. ${ }^{6}$, secara bahasa definisi

pendidikan mengandung arti bimbingan yang dilakukan oleh seseorang (orang dewasa) kepada anak-anak, untuk memberikan pengajaran, perbaikan moral dan melatih intelektual. Bimbingan kepada anak-anak dapat dilakukan tidak hanya dalam pendidikan formal yang diselenggarakan pemerintah, akan tetapi peran keluarga dan masyarakat dapat menjadi lembaga pembimbing yang mampu menumbuhkan pemahaman dan pengetahuan.

Berbagai teori yang dikembangkan saat ini telah mewarnai proses dan praktik pendidikan. Sumbangsih para tokoh dalam menciptakan teori telah memberikan perkembangan dan kemajuan dalam proses pendidikan. Lahirnya teori dalam bidang pendidikan memberikan warna baru terhadap sistem pendidikan, proses belajar mengajar, manajemen sekolah dan metode pembelajaran. Adanya pergeseran metode dan pola didik pengajar terhadap peserta didik merupakan proses dari pelaksanaan teori dalam bidang pendidikan. Sebagai contoh berkembangnya pola pendidikan active learning dimana proses pembelajaran tidak hanya terpusat pada pengajar akan tetapi peserta didik mempunyai peranan sangat menentukan hasil belajar. Hal ini dipelopori oleh teori yang berkembang yaitu teori behaviorisme dimana setiap manusia mempunyai kemampuan untuk berfikir dan melakukan setiap aktifitas dalam proses belajar. Sehingga dengan teori ini setiap peserta didik diberikan ruang kebebasan untuk melakukan kegiatan yang disesuaikan dengan kemampuan peserta didik, tugas pengajar bersifat pengarah dan fasilitator, hal ini memungkinkan terbentuknya rasa percaya diri serta kemampuan peserta didik untuk menciptakan

\footnotetext{
${ }^{5}$ Ellya Roza, "Naskah Melayu Digital: Sebuah Inovasi Sumber Kajian Pendidikan Islam Berbasis Information and Communication Technology (Ict)," POTENSIA: Jurnal Kependidikan Islam 5, no. 1 (2019): 44-63.

${ }^{6}$ Aas Siti Sholichah, "Teori-Teori Pendidikan dalam Al-Qur'an," Edukasi Islami: Jurnal Pendidikan Islam 7, no. 01 (2018): h. 25.
}

Al Qalam: Jurnal Ilmiah Keagamaan dan Kemasyarakatan Vol. 16, No. 1

Januari - Juni 2022 
hal-hal yang inovatif dan kreatif.

Teori pendidikan yang dikembangkan dunia Barat telah memberikan sumbangsih pada perkembangan ilmu pengetahuan di dunia, dalam berbagai praktek pola pendidikan yang bersumber dari Barat berorientasi pada sudut material dan menghasilkan keuntungan kepada manusia secara materi. Karena bersandar pada materi maka sesuatu yang tidak empiris dianggap mitos. Hal ini menyebabkan pola pikir manusia cenderung matrealistis, logis dan hanya berorientasi kepada akal.

Ada sisi lain yang sangat penting yang tidak tersentuh oleh pendidikan Barat adalah qalbu atau hati. Sehingga memungkinkan terjadinya kemampuan secara kognitif akan tetapi secara moral dan spiritual mengalami kekosongan. Ini dapat menimbulkan peluang sikap agresif, ambisius, dan persaingan antar sesama manusia sehingga menimbulkan kekerasan antar individu, golongan dan negara serta terjadi kehancuran terhadap dunia. ${ }^{7}$

\section{Pendidikan Berbasis Agama}

Sumber daya manusia yang handal merupakan penggerak utama dalam melestarikan dan menciptakan sumber daya alam yang potensial yang dapat digunakan untuk kelangsungan kehidupan manusia di bumi ini, hal ini sesuai dengan konsep pendidikan menurut M. Ilyasin yang mendefinisikan pendidikan sebagai upaya dalam mempersiapkan sumber daya manusia yang memiliki keahlian dan keterampilan sesuai tuntunan pembangunan bangsa. ${ }^{8}$

Islam menjelaskan pendidikan dengan berbagai istilah, salah satu istilah yang dapat mewakili dan memberikan rujukan mengenai konsep pendidikan adalah At-tarbiyyah. Kata "Attarbiyyah", berasal dari kata rabb yang berarti membina/ menumbuhkan sesuatu setahap demi setahap hingga mencapai batas yang sempurna. Kata "At-tarbiyyah", yang berkaitan dengan pendidikan dapat ditemukan dalam Al-Qur'an surat Ali- Imran/3: 79 sebagai berikut:

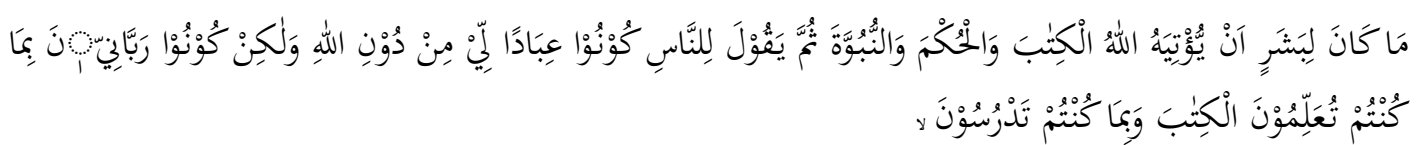

Tidak mungkin bagi seseorang yang telah diberi kitab oleh Allah, serta hikmah dan kenabian, kemudian dia berkata kepada manusia, "Jadilah kamu penyembahku, bukan penyembah Allah,” tetapi (dia berkata), "Jadilah kamu pengabdi-pengabdi Allah, karena kamu mengajarkan kitab dan karena kamu mempelajarinya!”

Kata "rabbânî", mengandung pengertian orang yang sempurna ilmu dan takwanya kepada Allah swt. Rabbânî adalah orang-orang yang memiliki ilmu pengetahuan yang sempurna yang terpanggil untuk mengajarkan ilmu dan kemampuan wawasan pengetahuan untuk disebarkan kepada masyarakat, dalam makna sederhana kata "rabbânî" dapat diartikan sebagai pengajar atau

\footnotetext{
${ }^{7}$ Sholichah, h. 24.

${ }^{8}$ Sholichah, h. 26.
}

Al Qalam: Jurnal Ilmiah Keagamaan dan Kemasyarakatan Vol. 16, No. 1 Januari - Juni 2022 


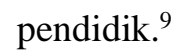

Begitu pentingnya islam memberikan ruang kepada setiap manusia untuk mendapatkan pendidikan, karena dengan ilmu dan pendidikan yang baik, manusia dapat mengelola alam dan menciptakan teknologi yang tidak dapat diciptakan oleh makhluk lain dan dengan ilmu pengetahuan, manusia menjadi makhluk yang paling sempurna. Sejalan dengan tujuan hidup manusia, tujuan pendidikan menurut Al-Ghazali adalah menjadi insan purna yang mendekatkan diri kepada Allah swt. dan menjadi insan purna yang bertujuan mendapatkan kebahagiaan di dunia dan akhirat. Isyarat tersebut sesuai dengan Al-Qur'an surat Al-Baqarah/2: 201:

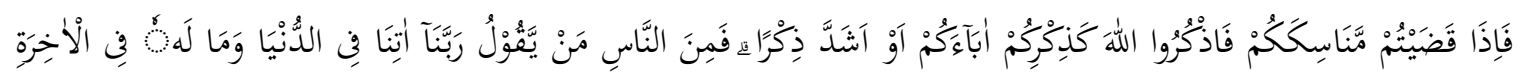

$$
\text { مِنْ خَلَاقِ }
$$

Apabila kamu telah menyelesaikan ibadah haji, maka berzikirlah kepada Allah, sebagaimana kamu menyebut-nyebut nenek moyang kamu, bahkan berzikirlah lebih dari itu. Maka di antara manusia ada yang berdoa, "Ya Tuhan kami, berilah kami (kebaikan) di dunia," dan di akhirat dia tidak memperoleh bagian apa pun.

Upaya yang dilakukan untuk memberikan pendidikan terhadap setiap manusia diharapkan dapat memberikan kebahagiaan dan ketenangan yang dapat dirasakan setiap manusia serta dapat memberikan nilai positif yang tertanam dalam diri manusia.

\section{Pendidikan Berbasis Filsafat}

Menurut faham konstruktivistik berbeda dengan faham klasik, pengetahuan itu adalah bentukan (konstruksi) siswa sendiri yang sedang belajar. Atau dengan kata lain, manusia membangun atau menciptakan pengetahuan dengan cara mencoba memberi arti pada pengetahuan sesuai dengan pengalamnnya. Pengetahuan itu rekaan dan tidak stabil, oleh karena itu pengetahuan adalah konstruksi manusia dan secara konstan manusia mengalami pengalaman-pengalaman baru, maka pengetahuan itu tidak pernah stabil. Oleh karena itu pemahan yang kita peroleh senantiasa bersifat tentatif dan tidak lengkap, pemahaman kita akan semakin mendalam dan kuat jika diuji melalui pengalaman-pengalaman baru. Dengan dasar itu, pembelajaran, pendidikan harus dikemas menjadi proses mengkonstruksi bukan menerima pengetahuan.

Dalam proses pembelajaran siswa membangun sendiri pengetahuan mereka melalui keterlibatan aktif dalam proses belajar mengajar. Siswa menjadi pusat kegiatan, bukan guru. Bentuk pembelajaran yang ideal adalah pembelajaran siswa yang aktif dan kritis. Siswa tidak kosong, tetapi sudah punya pengertian awal tertentu yang harus dibatu untuk berkembang. Maka modelnya adalah model dialogal, model konsistensi, model mencari bersama antara siswa dan guru. ${ }^{10}$

Jhon Dewey merupakan merupakan tokoh pembaharu pendidikan abad 20, konsep

\footnotetext{
${ }^{9}$ Abuddin Nata dan Fauzan, Filsafat Pendidikan Islam (Jakarta: Gaya Media Pratama, 2005), h. 92.

${ }^{10}$ Nurhadi dan Agus G.S, Pembelajaran Konstektual Dalam Penerapannya Dalam KBK (Malang: Universitas Negeri Malang, 2004), h. 33.
}

Al Qalam: Jurnal Ilmiah Keagamaan dan Kemasyarakatan Vol. 16, No. 1

Januari - Juni 2022 
pendidikan beraliran pendidikan progresif, dimana menempatkan pendidikan terpusat pada anak agar pengetahuan terorganisasi dipelajari demi tujuan-tujuan lain yang lebih besar. ${ }^{11}$

Teori merupakan pengetahuan ilmiah mencakup penjelasan mengenai suatu sektor tertentu dari disiplin ilmu dan dianggap benar. Berdasarkan hasil pengamatan, penelitaian yang mendalam mengenai disiplin ilmu tertentu. Teori pendidikan hadir dilatarbelakangi akan adanya kebutuhan dalam proses belajar mengajar. Berbagai teori pendidikan yang memberikan andil terhadap perkembangan proses belajar mengajar dan dapat menyelesaikan permasalahan pendidikan. Secara garis besar teori pendidikan dilatarbelakangi oleh aliran Empirisme, Nativisme, Konvergensi.

Aliran Empirisme menjelaskan bahwa pembentukan dan perkembangan manusia dalam menerima informasi dan pendidikan ditentukan oleh faktor lingkungan. Pelopor teori ini adalah John Lock (1632-1704) seorang yang berkebangsaan Inggris yang mempunyai gagasan bahwa segala sesuatu berada dalam pikiran dan hasil dari pengalaman inderawi bukan berasal dari akal budi. $^{12}$

Selain teori pendidikan tersebut di atas, Soyomukti menjelaskan beberapa teori pendidikan. Pertama, Pendidikan Tradisional. Teori ini menjelaskan bahwa sekolah dimaknai sebagai lembaga yang di dalamnya terdapat guru, siswa, sistem adminstrasi, alat bantu atau media pembelajaran yang baku (tradisional). Asal mula pendidikan tradisional ini adalah pesantren dan pendidikan anak di rumah atau sekarang lebih dikenal istilah homeschooling. Kedua teori pendidikan liberal. Teori ini menitikberatkan pada konsep seni liberal (liberal art). Konsep yang dibangun adalah dengan memberdayakan individu dengan pengetahuan yang luas, keterampilan, menekankan nilai-nilai, etika, dan kecakapan sipil. ${ }^{13}$

Dalam lingkup global teori ini termasuk kurikulum pendidikan secara umum yang menggunakan berbagai macam disiplin ilmu dan strategi pembelajaran untuk memaksimalkan potensi akademik siswa. Ketiga teori pendidikan Marxis-Sosialis. Teori ini berawal dari paham yang dibawa oleh Karl Mark yang lebih menekankan bidang ekonomi dan politik. Akan tetapi teori ini berkembang ke ranah pendidikan, dimana pendidikan dipahami untuk melihat fungsi pendidikan dalam masyarakat berkelas, secara historis, juga memiliki formulasi dan strategi pendidikan untuk menjadikan perubahan menuju kehancuran, ketimpangan, dan ketidakadilan sistem kapitalis. Pola pendidikan ini cukup berhasil di Negara penganut sosialis seperti Uni Soviet.

Dalam pendidikan marxis-sosialis berupaya menciptakan akan kesadaran keadaan pengajar, dan fasilitas. Nurani Soyomukti, material ekonomis, dan tenaga terdidik dan terlatih. Semua orang mempunyai hak yang sama tidak ada diskriminasi. Keempat teori pendidikan

\footnotetext{
${ }^{11}$ Nurani Soyomukti, Teori-Teori Pendidikan (Yogyakarta: Ar-Ruzz Media, 2010), h. 33.

${ }^{12}$ Harry Hamersma, Tokoh-Tokoh Filsafat Barat Modern (Jakarta: Gramedia, 1992), h. 19.

${ }^{13}$ Soyomukti, Teori-Teori Pendidikan, h. 155.
}

Al Qalam: Jurnal Ilmiah Keagamaan dan Kemasyarakatan Vol. 16, No. 1 Januari - Juni 2022 
Posmodernisme. Teori ini adalah bentuk reaksi dari teori modern. Jika merujuk pada filsafat, maka posmodernisme merupakan gaya berpikir yang lahir sebagai reaksi terhadap pikiran modernism yang dianggap mengalami banyak kekurangan dan menyebabkan berbagai masalah kemanusiaan. Postmodernisme berawal dari faham filsafat yang pada perkembangannya dijadikan teori kritis untuk berbagai macam bidang pengetahuan seperti sastra, drama, arsitektur, film, jurnalisme, desain, bidang pemasaran, bisnis sejarah dan lain sebagainya.

\section{Pendidikan Berbasis Psikologis}

Psikologi berasal dari bahasa Yunani, yaitu psyche yang berarti jiwa dan logos yang berarti ilmu. Jadi secara harfiah, psikologi berarti ilmu tentang jiwa atau ilmu jiwa. Defenisi berikut ini menunjukkan beragamnya pendapat para ahli tentang psikologi. ${ }^{14}$

a. Ernesrt Hilgert (1957) dalam bukunya Introduction to Psychology: "Psychology may be defined as the science that studies the behavior of men and other animal" etc. (psikologi adalah ilmu yang mempelajari tingkah laku manusia dan hewan lainnya).

b. George A. Miller dalam bukunya Psychology and Communication: "Psychology is the science that attempts to describe, predict, and control mental and behavioral events" (Psikologi merupakan ilmu yang berusaha menguraikan, meramalkan, dan mengendalikan peristiwa mental dan tingkah laku).

c. Clifford T. Morgan dalam bukunya Introduction to Psychology: "Psychology is the science of human and animal behavior" (Psikologi adalah ilmu yang mempelajari tingkah laku manusia dan hewan)

d. Robert S. Woodworth dab Marquis DG dalam bukunya Psychology: "Psychology is the scientifict studies of individual activities relation to the inveronment" (Psikologi adalah suatu ilmu pengetahuan yang mempelajari aktivitas atau tingkah laku individu dalam hubungan dengan alam sekitar).

Dari beberapa pendapat di atas menunjukkan rentangan makna psikologi dalam berbagai perspektif. Jika dilihat, terdapat beberapa perbedaan makna dari psikologi itu sendiri. Perbedaan tersebut boleh jadi disebabkan karena perkembangan psikologi itu sendiri. Apabila diamati berbagai defenisi psikologi di atas, terutama defenisi dari Morgan dan Hilgert, ternyata bahwa studi psikologi tidak hanya terbatas pada tingkah laku manusia saja, tetapi juga tingkah laku hewan. Hal ini semakin dipertegas oleh Chaplin, dalam Dictionary of psychology, yang mendefenisikan psikologi sebagai "...the science of human and animal behavior, the study of organism in all its variety and complexity as it respond to the flux andflow of the physical and social events which make up the environment" (...psikologi adalah ilmu pengetahuan tentang perilaku manusia dan hewan, juga

\footnotetext{
${ }^{14}$ Alex Sobur, Psikologi Umum (Bandung: Pustaka Setia, 2016), h. 32.
}

Al Qalam: Jurnal Ilmiah Keagamaan dan Kemasyarakatan Vol. 16, No. 1 Januari - Juni 2022 
penyelidikan terhadap organisme dalam segala ragam dan kemitraannya ketika mereaksi arus dan perubahan alam sekitar dan peristiwa-peristiwa kemasyarakatan yang mengubah lingkungan). ${ }^{15}$

Jadi pada dasarnya, psikologi itu menyentuh banyak bidang kehidupan dan organisme, baik manusia maupun hewan. Namun, meskipun demikian, secara lebih spesifik psikologi sering dikaitkan dengan kehidupan organisme manusia. Psikologi beserta sub-sub ilmunya, pada dasarnya mempunyai hubungan dengan ilmu-ilmu lainnya. Misalnya hubungan psikologi dengan sosiologi, antropologi, ilmu politik, ilmu komunikasi, biologi, ilmu alam, filsafat, dan ilmu pendidikan. Hubungan ini biasanya bersifat timbal balik.

Salah satu contohnya adalah hubungan psikologi dengan ilmu pendidikan, sehingga lahirlah namanya psikologi pendidikan. Pendidikan merupakan suatu usaha untuk memanusiakan manusia. Artinya, ditujukan untuk membentuk sikap dan mental peserta didik ke arah yang lebih baik. Sebagaimana yang dijelaskan di dalam UU RI No. 20 Tahun 2003, bahwa: "Pendidikan adalah usaha sadar dan terencana untuk mewujudkan suasana belajar dan proses pembelajaran agar peserta didik secara aktif mengembangkan potensi dirinya untuk memiliki kekuatan spiritual keagamaan, pengendalian diri, kepribadian, kecerdasan, akhlak mulia, serta keterampilan yang diperlukan dirinya, masyarakat, bangsa, dan negara. Dari penjelasan tersebut terlihat bahwa pskologi sangat diperlukan dalam mengembangkan potensi diri peserta didik.

Dari penjelasan di atas, maka dapat ditarik kesimpulan bahwa psikologi pendidikan adalah disiplin ilmu yang mempelajari tentang pemahaman gejala kejiwaan dalam tigkah laku manusia untuk kepentingan mendidik atau membina perkembangan kepribadian manusia. Jadi segala gejalagejala yang berhubungan dengan proses pendidikan dipelajari secara mendalam pada psikologi pendidikan.

Psikologi dan ilmu pendidikan tidak dapat dipisahkan satu dengan yang lainnya, karena antara psikologi dengan ilmu pendidikan mempunyai hubungan timbal balik. Ilmu pendidikan sebagai suatu disiplin bertujuan memberikan bimbingan hidup manusia sejak ia lahir sampai mati. Pendidikan tidak akan berhasil dengan baik jika tidak dibarengi dengan psikologi. Demikian pula watak dan kepribadian seseorang ditunjukkan oleh psikologi. Oleh karena begitu eratnya hubungan antara psikologi dengan ilmu pendidikan, maka lahirlah yang namanya psikologi pendidikan.

Dasar-dasar psikologis ini sangat dibutuhkan para pendidik untuk mengetahui prilaku anak didiknya, apakah anak didiknya dalam keadaan yang baik saat berlangsungnya kegiatan pembelajaran, atau dalam keadaan yang tidak baik. Kalau demikian, pendidik sangat membutuhkan pengetahuan ini untuk mengatasi anak didik yang seperti itu dan memotivasinya agar tetap dalam keadaan yang semangat dalam belajar. Selain untuk mengetahui prilaku anak didiknya, dasar-dasar

${ }^{15}$ Sobur, h. 33 .

Al Qalam: Jurnal Ilmiah Keagamaan dan Kemasyarakatan Vol. 16, No. 1 Januari - Juni 2022 
psikologis ini juga dapat mengendalikan prilaku para pendidik dan memberikan prilaku yang lebih bijaksana dalam menghadapi keanekaragaman karakteristik anak didiknya. Seorang pendidik memang sangat membutuhkan pengetahuan seperti ini, agar dalam proses pembelajaran dapat berjalan sesuai dengan yang diinginkan dan tentunya dapat berhasil mencapai tujuan dengan cemerlang sesuai dengan lembaga pendidikan itu.

Reber menyebut psikologi pendidikan sebagai subdisiplin ilmu psikologi yang berkaitan dengan teori dan masalah kependidikan yang berguna dalam hal-hal berikut: ${ }^{16}$

Penerapan dalam prinsip-prinsip belajar dalam kelasPengembangan dan pembaruan kurikulumUjian dan evaluasi bakat dan kemampuanSosialisasi proses dan interaksi dengan pendayagunaan ranah kognitif. Penyelenggaraan pendidikan keguruan. Dari penjelasan tersebut, maka jelas bahwa adanya keterkaitan antara psikologi dengan ilmu pendidikan, yang mana fokus utama dari psikologi pendidikan ini adalah interaksi pendidik dan peserta didik.

Kajian psikologi pendidikan dalam kaitannya dengan pengembangan kurikulum pendidikan terutama berkenaan dengan pemahaman aspek-aspek perilaku dalam konteks pembelajaran. Terlepas dari berbagai aliran psikologi yang mewarnai pendidikan, pada intinya kajian psikologis ini memberikan perhatian terhadap bagaimana input, proses dan output pendidikan dapat berjalan dengan tidak mengabaikan aspek perilaku dan kepribadian peserta didik.

Secara psikologis, manusia merupakan individu yang unik. Manusia sebagai makhluk yang unik, memiliki karakteristik masing-masing, kemampuan yang berbeda, serta kebutuhan yang berbeda pula. Maka bukanlah hal yang mengejutkan jika ada sekelompok siswa yang tidak cocok dengan sistem pendidikan formal. Jika siswa tidak dapat mengikuti pendidikan formal di sekolah karena alasan tertentu, ia berhak untuk memilih pendidikan alternatif lain yang dapat memenuhi haknya sebagai warga negara untuk belajar, karena setiap anak berhak mendapatkan pendidikan, dalam bentuk apapun. Dengan demikian, kajian psikologis dalam pengembangan kurikulum seyogyanya memperhatikan keunikan yang dimiliki oleh setiap individu, baik ditinjau dari segi tingkat kecerdasan, kemampuan, sikap, motivasi, perasaaan serta karakterisktik-karakteristik individu lainnya.

Kurikulum pendidikan seyogyanya mampu menyediakan kesempatan kepada setiap individu untuk dapat berkembang sesuai dengan potensi yang dimilikinya, baik dalam hal subjekt materi maupun metode penyampaiannya. Secara khusus, dalam konteks pendidikan di Indonesia saat ini, kurikulum yang dikembangkan saat ini adalah kurikulum 2013, yang pada intinya diperlukan tidak hanya pengetahuan saja, tetapi sikap, keterampilan dan pengetahuan. Sebenarnya ketiga domain ini sudah ada pada kurikulum sebelumnya, tetapi ternyata belum membawa dampak

${ }^{16}$ Sobur, h. 71.

Al Qalam: Jurnal Ilmiah Keagamaan dan Kemasyarakatan Vol. 16, No. 1 Januari - Juni 2022 
yang cukup signifikan, karena apa yang ada belum diimplementasikan secara utuh. Kurikulum 2013 dirancang untuk mengembangkan keseimbangan antara pengembangan sikap spiritual dan sosial, rasa ingin tahu, kreativitas, kerja sama dengan kemampuan intelektual dan psikomotorik. Berdasarkan penjelasan di atas, terlihat bahwa psikologi pendidikan sangat berkontribusi dalam pengembangan kurikulum.

\section{Pendidikan Berbasis Sosiologis}

Sosiologi merupakan ilmu yang mempelajari hubungan antara manusia dalam kelompokkelompok dan struktur sosialnya. Landasan sosiologi pendidikan adalah seperangkat asumsi yang dijadikan titik tolak dalam rangka praktek dan atau studi pendidikan yang bersumber sosiologi. Sosiologi pendidikan meliputi: interaksi guru-guru dengan siswa, dinamika kelompok kelas atau sekolah, struktur dan fungsi pendidikan, serta sistem-sistem masyarakat dan pengaruhnya terhadap pendidikan.

Berdasarkan analisis sosiologi memiliki peran yang penting dalam pendidikan sebagai acuan atau dasar dalam rangka mencapai tujuan dari pendidikan, dasar atau acuan. Konsep dan teori sosiologi pendidikan memberi petunjuk kepada guru-guru bagaimana seharusnya membina para siswa agar mereka memiliki kebiasaan saling kerjasama, rukun, bersahabat, saling membantu sesama teman dan saling menghormati sesama teman. Implementasi landasan sosiologi dalam pendidikan bisa dilaksanakan dalam beberapa kegiatan sosiologi dalam pendidikan diantaranya: Sosialisasi anak-anak dalam pendidikan, proses sosialisai anak-anak, kewajiban sekolah untuk mengembangkan aspek itu pada diri anak-anak. Peranan pendidikan dalam masyarakat, dukungan masyarakat terhadap pendidikan. Implikasi landasan sosiologi terhadap pendidikan adalah keberadaan sekolah tidak dapat dipisahkan dengan masyarakat sekitarnya, perlu dibentuk badan kerja sama antara sekolah dengan tokoh-tokoh masyarakat, proses sosialisasi anak perlu ditingkatkan, dinamika kelompok dimnfaatkan untuk belajar. ${ }^{17}$

Manusia merupakan makhluk sosial, mereka membutuhkan orang lain. Sejak manusia dilahirkan di dunia, sesungguhnya ia telah belajar dan berkenalan dengan hubungan-hubungan sosial. Hubungan sosial manusia mengacu pada hubungan antar individu, antar masyarakat, dan individu dengan masyarakat. Hubungan sosial dimulai dari hubungan antara anak dengan orang tua kemudian meluas hingga ketetangga.

Dalam hubungan sosial tersebut terjadilah proses pengenalan dan proses pengenalan tersebut mencakup berbagai budaya, nilai, norma dan tanggung jawab manusia, sehingga dapat tercipta corak kehidupan masyarakat yang berbeda-beda dengan masalah yang berbeda pula. Sosiologis adalah ilmu yang mempelajari hubungan antara manusia dalam kelompok-kelompok dan

${ }^{17}$ Satriadin Satriadin, "Landasan Sosiologis Dalam Pendidikan," JISIP (Jurnal Ilmu Sosial dan Pendidikan) 1, no. 2 (2017): h. 101.

Al Qalam: Jurnal Ilmiah Keagamaan dan Kemasyarakatan Vol. 16, No. 1 Januari - Juni 2022 
struktur sosialnya. ${ }^{18}$ Jadi dalam ilmu sosiologi mempelajari tentang bagaimana hubungan antara manusia satu dengan yang lain, bagaimana susunan unit masyarakat atau sosial di wilayah serta kaitanya dengan yang lain. Sosiologi diperlukan dalam pendidikan karena konsep dan teori dari sosiologi memberikan petunjuk kepada guru-guru tentang bagaimana seharusnya mereka membina para siswa, agar mereka memiliki kebiasaan akrab, harmonis bersahabat sesama teman.

Antara sosiologi dan sosiologi pendidikan saling terkait. Sosiologi memberikan bantuan pada pendidikan dalam wujud sosiologi pendidikan. Dengan demikian ilmu sosiologi memiliki peran yang penting dalam pendidikan sebagai acuan atau dasar dalam rangka mencapai tujuan dari pendidikan, dasar atau acuan disebut dengan landasan. Jadi landasan sosiologis pendidikan merupakan dasar atau acuan yang dijadikan acuan dalam mencapai tujuan pendidikan yang bersumber dari sosiologis. Berdasakan konteks masalah diatas, maka perlu dipetakan ulang, dideskripsikan secara lebih lanjut mengenai bagaimana landasan sosiologis

\section{KESIMPULAN DAN SARAN}

Hakikat pendidikan adalah proses pembelajaran sebagai upaya untuk mengembangkan aktivitas dan kreativitas peserta didik dengan interaksi yang menghasilkan pengalaman belajar. Di Indonesia menginginkan pendidikan yang lebih baik, hal inilah yang melatar belakangi terjadinya pergantian kurikulum secara terus-menerus. Pergantian kurikulum merupakan salah satu usaha yang dilakukan negara dalam mencetak lulusan yang berkualitas dalam negara kekuasaannya maupun internasional agar sesuai dengan fungsi dan tujuan pendidikan nasional sebagaimana tercantum dalam UU No. 20 Tahun 2003.

Pendidikan dapat dikatakan berhasil dan mencapai tujuan jika terjadi perubahan. Perubahan tersebut ialah perubahan tingkah laku, yang memiliki beberapa aspek yaitu: 1) pengetahuan, 2) pengertian, 3) kebiasaan, 4) keterampilan, 5) apresiasi, 6) emosional, 7) hubungan sosial, 8) jasmani, 9) budi pekerti, 10) sikap. Dalam pendidikan siswa dituntun untuk aktif, inovatif dan kreatif dalam merespon materi. Kenyataannya guru dianggap sebagai satu-satunya sumber belajar (teaching center) yang menyebabkan siswa menjadi pasif sehingga dalam proses pembelajaran menjadi bosan. Pembelajaran adalah sebuah usaha mempengaruhi emosi, intelektual dan spiritual seseorang agar ingin belajar dengan kehendaknya sendiri, sedangkan belajar yaitu suatu proses yang berakhir pada perubahan.

Dengan demikian hakikat pendidikan adalah sangat ditentukan oleh nilai-nilai, motivasi dan tujuan dari pendidikan itu sendiri. Maka hakikat pendidikan dapat dirumuskan sebagi berikut :

1. Pendidikan merupakan proses interaksi manusiawi yang ditandai keseimbangan antara

${ }^{18}$ Made Pidarta, Landasan Kependidikan Stimulus Ilmu Pendidikan Bercorak Indonesia (Jakarta: PT Rineka Cipta, 2007), h. 151.

Al Qalam: Jurnal Ilmiah Keagamaan dan Kemasyarakatan Vol. 16, No. 1

Januari - Juni 2022 
kedaulatan subjek didik dengan kewibawaan pendidik;

2. Pendidikan merupakan usaha penyiapan subjek didik menghadapi lingkungan yang mengalami perubahan yang semakin pesat;

3. Pendidikan meningkatkan kualitas kehidupan pribadi dan masyarakat;

4. Pendidikan berlangsung seumur hidup; Pendidikan merupakan kiat dalam menerapkan prinsip-prinsip ilmu.

\section{SARAN DAN REKOMENDASI}

Kita sepakat bahwa pendidikan merupakan sesuatu yang tidak asing bagi kita, terlebih lagi karena kita bergerak di bidang pendidikan. Juga pasti kita sepakat bahwa pendidikan diperlukan oleh semua orang. Bahkan dapat dikatakan bahwa pendidikan ini dialami oleh semua manusia dari semua golongan. Tetapi seringkali orang melupakan makna dan hakikat pendidikan itu sendiri. Layaknya hal lain yang sudah menjadi rutinitas, cenderung terlupakan makna dasar dan hakikatnya. Karena itu benarlah kalau dikatakan bahwa setiap orang yang terlihat dalam dunia pendidikan sepatutnyalah selalu merenungkan makna dan hakikat pendidikan, merefleksikannya di tengahtengah tindakan/aksi sebagai buah refleksinya.

\section{DAFTAR PUSTAKA}

Abas, Ros Arianti. "Konsep Kecerdasan Majemuk Perspektif howard Gardner Dan Penerapanya Dalam Pembelajaran Pendidikan Agama Islam Di Sekolah," 2016.

Hamersma, Harry. Tokoh-Tokoh Filsafat Barat Modern. Jakarta: Gramedia, 1992.

Marwiyah, Syarifatul. "Konsep Pendidikan Berbasis Kecakapan Hidup.” Jurnal Falasifa 3, no. 1 (2012): 75-97.

Nata, Abuddin, dan Fauzan. Filsafat Pendidikan Islam. Jakarta: Gaya Media Pratama, 2005.

Nurhadi, dan Agus G.S. Pembelajaran Konstektual Dalam Penerapannya Dalam KBK. Malang: Universitas Negeri Malang, 2004.

Pidarta, Made. Landasan Kependidikan Stimulus Ilmu Pendidikan Bercorak Indonesia. Jakarta: PT Rineka Cipta, 2007.

Roza, Ellya. "Naskah Melayu Digital: Sebuah Inovasi Sumber Kajian Pendidikan Islam Berbasis Information and Communication Technology (Ict)." POTENSIA: Jurnal Kependidikan Islam 5, no. 1 (2019): 44-63.

Satriadin, Satriadin. "Landasan Sosiologis Dalam Pendidikan.” JISIP (Jurnal Ilmu Sosial dan Pendidikan) 1, no. 2 (2017).

Sholichah, Aas Siti. “Teori-Teori Pendidikan dalam Al-Qur'an.” Edukasi Islami: Jurnal Pendidikan Islam 7, no. 01 (2018): 23-46.

Sobur, Alex. Psikologi Umum. Bandung: Pustaka Setia, 2016.

Soyomukti, Nurani. Teori-Teori Pendidikan. Yogyakarta: Ar-Ruzz Media, 2010.

Sukardjo, M, dan Ukim Komarudin. Landasan Pendidikan Konsep dan Aplikasi. Jakarta: PT Raja

Al Qalam: Jurnal Ilmiah Keagamaan dan Kemasyarakatan Vol. 16, No. 1

Januari - Juni 2022 
Grafindo Persada, 2010.

Triwiyanto, Teguh. Pengantar Pendidikan. Jakarta: PT Bumi Aksara, 2014.

Al Qalam: Jurnal Ilmiah Keagamaan dan Kemasyarakatan Vol. 16, No. 1 Januari - Juni 2022 